\title{
Differential behaviour of a Lesser Himalayan watershed in extreme rainfall regimes
}

\author{
Pankaj Chauhan ${ }^{1, *}$ (D) Nilendu Singh ${ }^{1}$, Devi Datt Chauniyal ${ }^{2}$, \\ Rajeev S Ahluwalia ${ }^{1}$ and Mohit Singhal ${ }^{1}$ \\ ${ }^{1}$ Wadia Institute of Himalayan Geology, Dehradun 248 001, India. \\ ${ }^{2}$ School of Earth Science, HNB Garhwal University, Srinagar 246 174, India. \\ *Corresponding author.e-mail: pchauhan1008@gmail.com
}

Climatic extremes including precipitation are bound to intensify in the global warming environment. The present study intends to understand the response of the Tons sub-watershed in Lesser Himalaya, in 3 years with entirely different hydrological conditions (July 2008-June 2011) in terms of discharge, sediment flux and denudation rates. Within an uncertainty limit of $\pm 20 \%$, the mean interannual discharge (5.74 $\left.\pm 1.44 \mathrm{~m}^{3} \mathrm{~s}^{-1}\right)( \pm \mathrm{SE})$, was found highly variable $\left(\mathrm{CV}: 151 \% ; 0.8-38 \mathrm{~m}^{3} \mathrm{~s}^{-1}\right)$. In a normal rainfall year (2008-2009; $1550 \mathrm{~mm})$, the discharge was $5.12 \pm 1.75 \mathrm{~m}^{3} \mathrm{~s}^{-1}$, whereas in a drought year $(2009-2010)$, it reduced by $30 \%$ with the reduction in $\sim 23 \%$ rainfall (CV: $85 \%$ ). In an excessive rainfall year (once-in-acentury event) (2010-2011; $\sim 3050 \mathrm{~mm}$ ), discharge as well as total solid load was $\sim 200 \%$ higher. Monsoon months (July-September) accounted for more than $90 \%$ of the annual solid load transport. The ratio of dissolved to suspended solid $(\mathrm{C} / \mathrm{P}$ ratio) was consistently low $(<1)$ during monsoon months and higher $(1-7)$ during the rest of the dry period. $\mathrm{C} / \mathrm{P}$ ratio was inversely $\left(R^{2}=0.49\right)$, but significantly $(P<0.001)$ related to the rainfall. The average mechanical erosion rate in the three different rainfall years was 0.24 , 0.19 and $1.03 \mathrm{mmyr}^{-1}$, whereas the chemical erosion was estimated at $0.12,0.11$ and $0.46 \mathrm{mmyr}^{-1}$, respectively. Thus, the average denudation rate of the Tons sub-watershed has been estimated at 0.33 $\mathrm{mmyr}^{-1}$ (excluding extreme rainfall year: $1.5 \mathrm{mmyr}^{-1}$ ). Our results have implications to understand the hydrological behaviour of the Lesser Himalayan watersheds and will be valuable for the proposed and several upcoming small hydropower plants in the region in the context of regional ecology and natural resource management.

\section{Introduction}

Hydropower harvesting in mountainous streams could significantly improve the rural economy (Choden 2009). There are several small hydropower plants (SHPPs) in the western Lesser Himalayan region which are being planned for rural energy supply and development of multipurpose schemes such as irrigation, fishery, recreation and tourism (Kesharwani 2006). Due to higher rate of reservoir sedimentation and sand erosion of turbines, the sustainability of many of these projects, however, is debatable (Pradhan 2004; Weerakoon and Rathnayake 2007). Thus, the aim of the present study is to access the crucial hydrological behaviour in a typical Lesser Himalayan catchment in terms of discharge, erosion, sediment flux and denudation rates and its implications

Keywords. Tons river basin; sediment flux; denudation rate; small hydropower plants; extreme precipitation; Lesser Himalaya. 
on SHPPs in the region. The behaviour is also described in light of extreme to normal rainfall year regimes.

Heavy rainfall events are bound to increase in the warming global environment and have strikingly increased in the past 30 years (Thomas and Christoph 2005). The global average increase is $\sim 12 \%$, whereas for Asia, it is above $50 \%$ (Lehmann et al. 2015). Good et al. (2015) reported that only $38 \%$ of the rainfall interacts with soil or plant, the rest directly transforms into runoff. Therefore, proper management and conservation of water is essential for development. Hence, in recent years, the hydrology of the Himalaya has received considerable attention among researchers and environmentalists. Continued emphasis on research in this direction has been given to quantify water discharge and estimate sediment budget by the different ecohydrological processes in the catchments (Caine and Swanson 1989).

Geologically precarious Himalayan terrain with high rainfall may be the cause of high natural erosion rates (Nagle et al. 1999). The annual sediment yield of different Indian Himalayan catchments has been presented in table 1 , which indicates variable annual sediment yield over space as well as time.

Several workers have estimated the regional erosion rates: for the Himalaya (Menard 1961: 1.0 mmyr $^{-1}$ ), Ganga/Brahmaputra (Curray and Moor 1971: $0.7 \mathrm{mmyr}^{-1}$ ) and central part of the Himalaya Rawat and Rawat 1994: $\left.0.10 \mathrm{mmyr}^{-1}\right)$. Operational over different time scales (Kyr-Myr), erosion rate in the central Himalaya estimated by Valdiya and Bartarya (1989) is $1.7 \mathrm{mmyr}^{-1}$. Lupker et al. (2012) observed $\sim 1.0 \mathrm{mmyr}^{-1}$ in the Ganga river system, in Punatsanchhu river (Bhutan) (Choden 2009: $0.28 \mathrm{mmyr}^{-1}$ ) and Das (1968) reported $0.51 \mathrm{mmyr}^{-1}$ in Arun river watershed, Himalaya.

Based on limited studies on the denudation rate in the Lesser Himalayan watersheds, it was found that the rate was highly variable both temporally as well as spatially (Rawat and Rawat 1994; Rawat et al. 2012b). In this region, the erosion rates are 5-6 times higher than the average erosion rate $\left(1.0 \mathrm{mmyr}^{-1}\right.$ ) for the Himalaya (Lupker et al. 2012).

Rainfall and landslides are some of the factors that contribute to this accelerated rate of erosion in the Lesser Himalaya (Bartarya 1988; Rawat and Rawat 1994; Rawat et al. 2011). Several anthropogenic factors also contribute to this acceleration, such as poorly managed agriculture, deforestation, mining and substandard construction of roads and proliferating tourism. Increasing population and demand of land for agriculture have also increased pressure on the watersheds of the Lesser Himalayan region (Barnard et al. 2001; Rawat et al. 2011). In this regard, Chauhan et al. (2016) proposed a methodology based on integrated and comprehensive micro-watershed prioritization to demarcate the most suitable site for the installation of SHPP in a watershed. Hence, looking into the geological fragility, lack of quantitative studies on sediment fluxes and prospects of the region in developing small hydropower plants on sustainable basis, we set forth the following objectives: to detail the hydrological behaviour in terms of (1) water discharge, (2) erosion and sediment flux, and (3) denudation rates in the context of normal to extreme rainfall years with implications on the SHPPs.

\section{The study area}

To represent a typical western Lesser Himalayan watershed where many small multipurpose hydropower projects are being planned, the Tons River basin with an area of $\sim 41.2 \mathrm{~km}^{2}$ (a subwatershed and tributary of the Asan River), has been selected for the study $\left(78^{\circ} 00^{\prime} 56^{\prime \prime}-78^{\circ} 05^{\prime} 44^{\prime \prime} \mathrm{E}\right.$; $30^{\circ} 22^{\prime} 12^{\prime \prime}-30^{\circ} 27^{\prime} 50^{\prime \prime} \mathrm{N}$ ). The river originates from the southern slopes of Mussoorie hills $(2190 \mathrm{~m})$ and joins the major river Asan in the Doon valley plains $(600 \mathrm{~m})$ (figure 1$)$. Its two major tributaries

Table 1. Annual sediment yield at different sites in Indian Himalayan catchments.

\begin{tabular}{lllcl}
\hline & & & \multicolumn{3}{c}{ Sediment yield } \\
State & Basin & Station & $\left(\mathrm{t} \mathrm{km}^{-2} \mathrm{yr}^{-1}\right)$ & \multicolumn{1}{c}{ Source } \\
\hline Uttarakhand & Tons & Gucchupnai & 894 & Present study \\
Himachal Pradesh & Giri & Dadahu & 957 & Chaudhary and Sharma (1999) \\
J\&K & Chenab & Sirsi & 939 & Rao et al. (1997) \\
J\&K & Chenab & Kuriya & 878 & Rao et al. (1997) \\
Himachal Pradesh & Kinnaur & Wangtu & 1597 & Sharma et al. (1991) \\
Uttarakhand & Gaula & Kathgodam & 3703 & Valdiya and Bartarya (1989) \\
Uttarakhand & Nana Kosi & Nana Kosi & 200 & Rawat and Rawat (1994) \\
Uttarakhand & Khulgad & Khulgad & 186 & Rawat and Rai (1997) \\
Haryana & Yamuna & Tajwala & 2178 & Jha et al. (1988) \\
Uttarakhand & Dabka & Jalna & 222 & Rawat et al. (2012a) \\
\hline
\end{tabular}




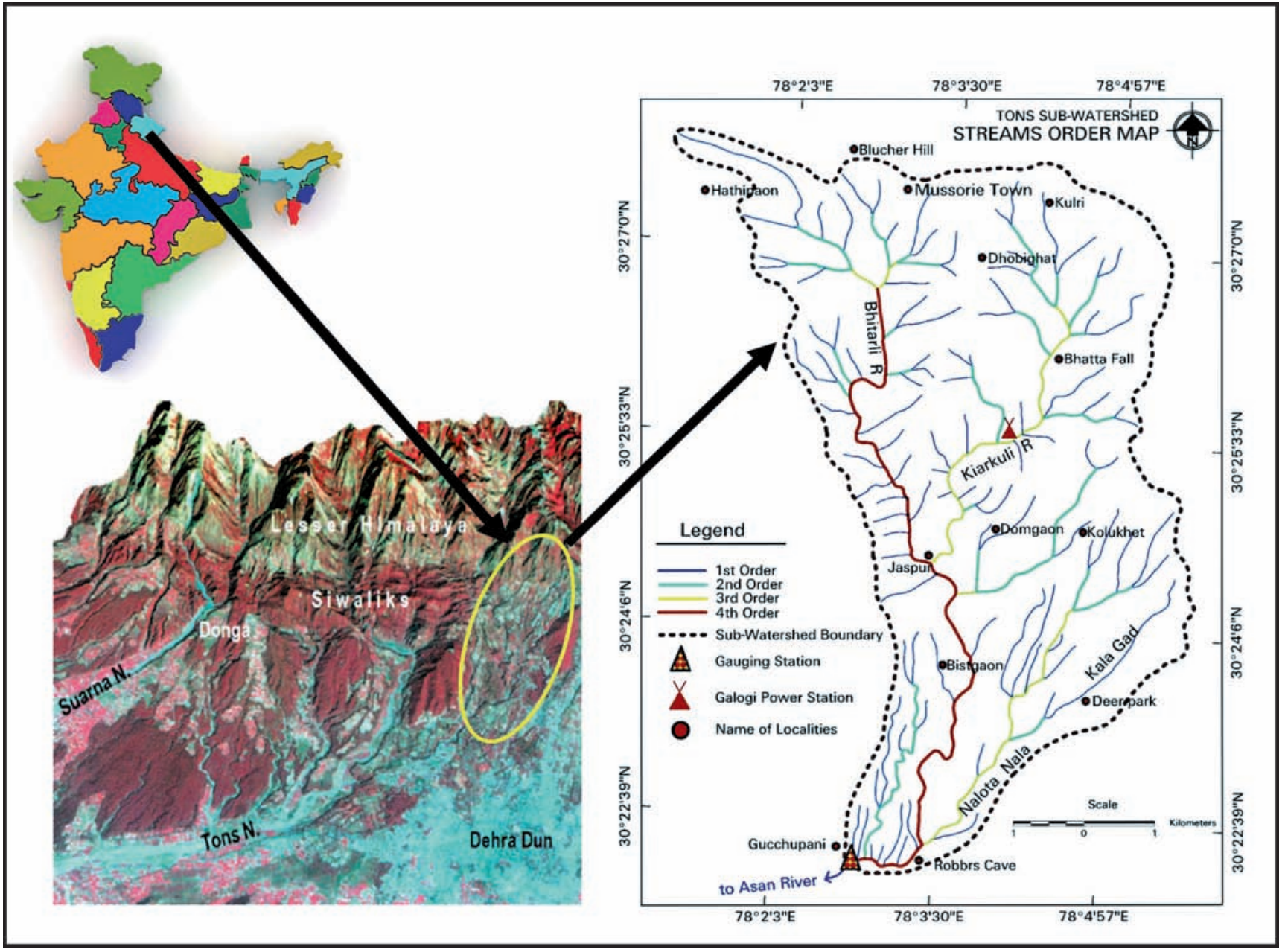

Figure 1. Location map of Tons River basin, showing topography and the river systems in the Doon valley (left panel). Streams order and discharge site in the basin (right panel).

are Bhitarli and Kiarkuli rivers. The study area falls in a sensitive and fragile zone of the Mussoorie hills which is affected by the landslides (Yadav and Sri Ram 2014).

Average annual temperature is $\sim 22^{\circ}$, hottest months are May and June and coldest are December and January. The monsoon months are from end of June to mid of September, the area receives an average annual rainfall of 1500-1600 $\mathrm{mm}$.

Geologically, the area refers to the litho-tectonic zone lying south of the Main Boundary Thrust (MBT) and is separated to the north by the Main Central Thrust (MCT). It predominantly consists of Proterozoic-Cambrian shelf to shallow marine sequences exposed in two main belts: the inner carbonate belt and the outer Krol belt. The stratigraphy of the Mussoorie syncline consists largely of sedimentary rocks of Krol belt. It is separated from the Siwaliks by the MBT in the Lesser Himalaya at 1500-2500 $\mathrm{m}$ height (figure $2 \mathrm{~b}$ ).

Soil property influences soil erosion and landslide activities. Physical properties of the soil, in and around the study area have been carried out by Srivastava (2005): soil depth $(20-30 \mathrm{~cm})$, soil moisture $(12.2 \pm 0.4 \%)$, pH $(7.3 \pm 0.2)$, conductivity $(0.02 \pm 0.0 \mathrm{ds} / \mathrm{m})$ and water holding capacity $(52.8 \pm 4.7 \%)$. Soil map has been prepared (figure 2a) with soil type classes: fine-loamy, loamy-skeletal, loamy-gravelly, loamy-mixed, finesilt, silt-clay, sandy-clay and sandy-loamy, with the help of available literature and correlated with the map prepared by Alternate Hydro Energy Centre (AHEC), an academic centre of Indian Institute of Technology, Roorkee and Agriculture and Soil Division of Indian Institute of Remote Sensing, (IIRS), Dehradun.

Geomorphologic parameters and land use pattern of this watershed have also been prepared which would help in understanding hydrological responses and scientific planning for development. The total area of the sub-watershed has been classified and categorized as per land use/land cover area, viz., forest cover (including open forest, dense forest, scrub and plantation): $17.5 \mathrm{~km}^{2}$ (45.4\%), cultivated land: $7.8 \mathrm{~km}^{2}(19 \%)$, uncultivated and rocky area: $6.8 \mathrm{~km}^{2}(16.5 \%)$, wasteland 

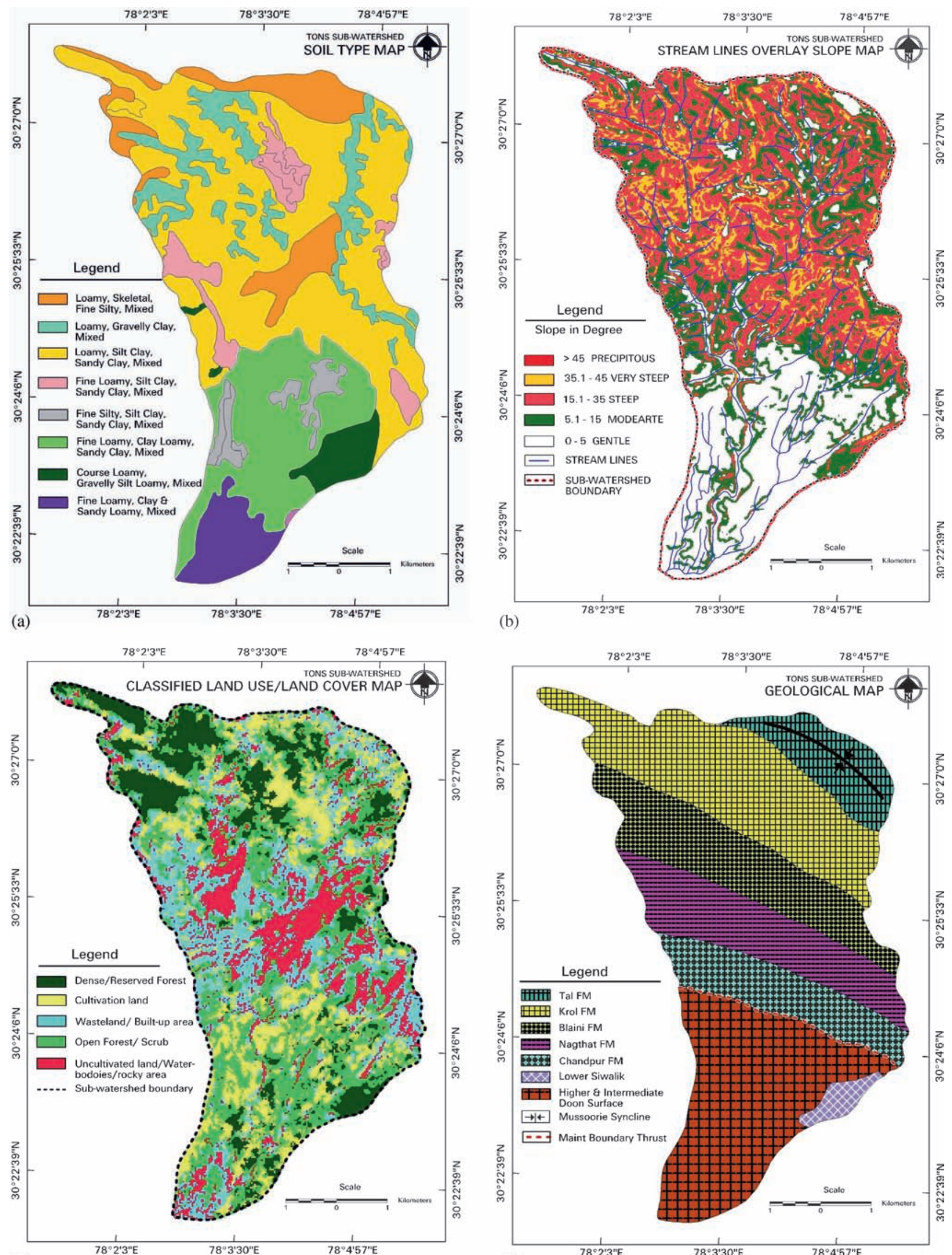

(b)

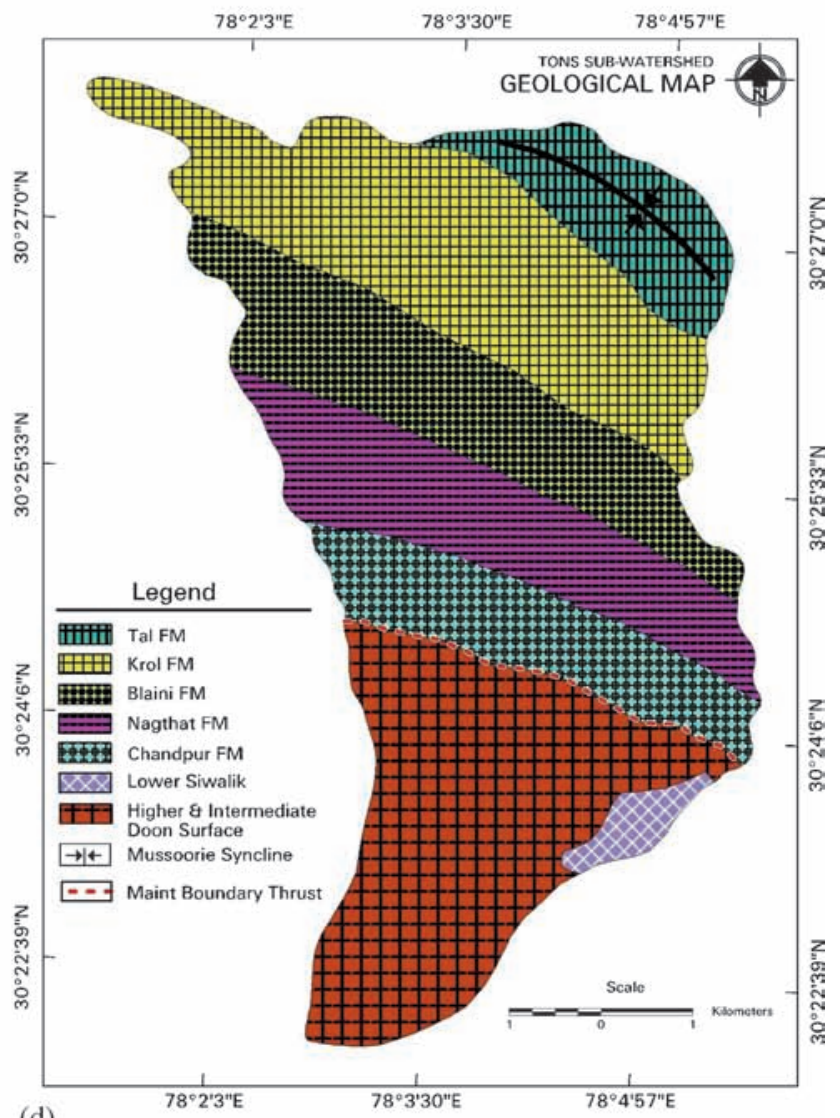

(d)

Figure 2. Geo-environmental maps of the catchment area: (a) soil type, (b) geological formation, (c) land use/land cover classification, and (d) slope analysis and their category. 
and built-up area: $9.1 \mathrm{~km}^{2}(22.1 \%)$ (figure 2c). Stream morphometric analysis of the Tons River has been quantified as the 4th order drainage basin, which flows through a very steep gradient $\left(>40^{\circ}-5^{\circ}\right)$. The average slope of the catchment has been calculated as $6^{\circ}$ (figure $2 \mathrm{~d}$ ).

\section{Materials and methods}

To understand the nature and characteristics of the catchment, as a part of this study, geoenvironmental map has been prepared which covers soil, geology, land use and slope (figure $2 \mathrm{a}-\mathrm{d}$ ). These maps address the rate of erosion and segmentation within the catchment. These maps have been prepared with the help of updated topographical maps along with Indian Remote Sensing Satellite (IRS) LISS-III and PAN satellite data (Path: 146, Row: 039). Remote sensing and Geographical Information System (GIS) software, e.g., Erdas Imagine 9.0 and Arc GIS 9.1 have been used for preparing these maps. A narrow gauging station $(20 \mathrm{~m} \times 20 \mathrm{~m})$ was constructed at the outlet of the basin, near Gucchupani (figure 1) to monitor water discharge and sediments. This is elaborated in equation (1), where $A$ is the water channel crosssectional area $\left(\mathrm{m}^{2}\right)$, and $V$ is the velocity of water discharge $\left(\mathrm{ms}^{-1}\right)$.

$$
\text { Stream discharge }\left(\mathrm{m}^{3} \mathrm{~s}^{-1}\right)=A \times V
$$

$$
\begin{aligned}
& \text { Denudation rate }\left(\mathrm{mmyr}^{-1}\right) \\
& \quad=\frac{\left(\frac{\text { total load in tones in yr }}{\text { total area of watershed }(\mathrm{km})^{2} \times \text { specific density }}\right)}{1000}
\end{aligned}
$$

where 1000 is kiloannum (1000 years).

Float method (Buchanan and Somers 1969) is applied at the gauging site for collection of water samples and measurement of velocity and discharge for estimation of suspended and dissolved load.

A depth resolved sediment gauging gives better estimation, but due to lack of proper logistic, it was not carried out in the field. Coarse particles dominate bed load. Bed load in most cases remains less than the suspended load (Xiaoping 2003). The accurate measurement of coarse bed load transported from mountain streams was not possible to estimate for us in the river section. Although, deposited bed load has been estimated in the present study, using a pebble count method (Wolman 1954) on the basis of an average weight and size. However, some studies have suggested the simple experimental relationship between suspended load and bed load. It has also been quantified that the ratio of bed load to the suspended sediment load constructed on annual loads amounts to about $0.05-0.15(5-15 \%)$ with a possible estimation error of $\pm 5 \%$ (Fergusson 1984; Bhutiyani 2000; Sitaula et al. 2007; Singh et al. 2008). As per used method (Wolman 1954), in the present study, bed load has been estimated at about $13 \%$ of the suspended load, which is in conformity of the several studies $(5-15 \%$ of suspended load). Therefore, the bed load has been considered to be of $13 \%$ of the suspended sediment load in the present study.

The denudation rates were estimated following equation (2), using an average density of the rock or soil at the study site $\left(2.7 \mathrm{gm} / \mathrm{c}^{3}\right)$. The sediment data and water samples have been collected on daily, weekly or monthly basis, during normal dry months and rainy season. The water samples were tested and analyzed at the sedimentological laboratory of WIHG, Dehradun, for the calculation of suspended and dissolved load. $100 \mathrm{ml}$ water was filtered through Whatman filter paper and the material collected was weighted. Filtered water was then evaporated in an oven at $100^{\circ} \mathrm{C}$, for the calculation of dissolved load using gravimetric method. The rainfall, humidity, temperature, etc., data have been collected from a metrological station installed by the Forest Research Institute (FRI), Dehradun (FRI, Forest Ecology and Environment Division, Meteorological Data Archive; http://fri.icfre.gov.in).

Modern denudation estimates are usually based on stream load measurements taken at gauging station, where suspended, dissolved and bed load are included. The weight of the load is converted to volumetric units and the load volume is divided by the area with multiple of average specific density of the rocks in the watershed. In the present study, average specific density has been taken on the basis of geology and rock type formation (equation 2).

A MATLAB package available from Torrence and Compo (1998) was used for the wavelet and power spectrum analysis. The significance tests for wavelet coherence and the cross-wavelet spectra are based on Monte Carlo simulations (Grinsted et al. 2004).

\section{Results}

\subsection{Water discharge behaviour}

The study region (sub-tropics) receives fairly good amount of monsoon (July-September) rainfall (1500-1600 mm). The annual rainfall behaviour is unimodal with usual peak in July-August (500-550 $\mathrm{mm})$. The region also receives some pre-monsoon (March-April) (14\%) and winter (December-January) (4\%) rainfall from western disturbances (Singh et al. 2008; Dimri et al. 2016). 

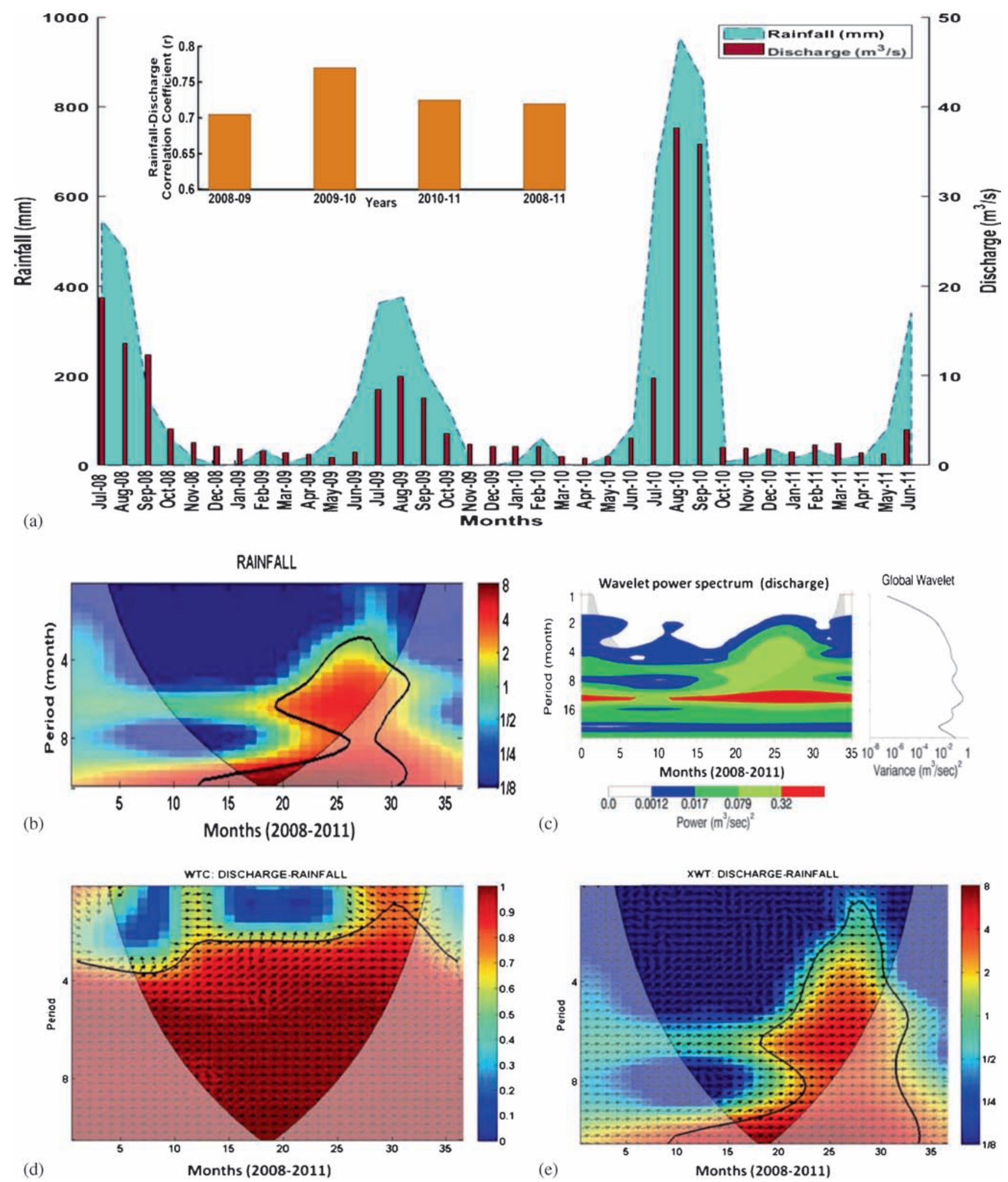

Figure 3. (a) The rainfall-discharge behaviour of the catchment in the study period (inset figure shows correlation coefficient $(r)$ in the different hydrological years). The continuous wavelet power spectrum of (b) rainfall during study period (thick black contour designates the $5 \%$ significance level against red noise and the cone of influence), (c) the wavelet power spectrum of discharge and its global wavelet power spectrum (the cross-hatched region is the cone of influence where zero padding has reduced the variance). There is more concentration of power between the 11-13 month band, which shows that this time series has a strong annual signal, (d) squared wavelet coherence, and (e) cross wavelet transform between the standardized discharge and rainfall time series. (The $5 \%$ significance level against red noise is shown as a thick contour. All significant sections show in-phase behaviour. Arrows show the phase shift between the respective time series. Colours indicate the measure of coherence: red colour implies high degree of coherence. Arrows pointing right indicate that the two time series are in phase. Arrows pointing down indicate that precipitation leads to discharge.) 
Annual and interannual discharge behaviour has been illustrated in figure $3(\mathrm{a}-\mathrm{e})$ and in tables 2 and 3 . The average rate of discharge by the watershed is $5.74 \pm 1.44 \mathrm{~m}^{3} \mathrm{~s}^{-1}( \pm \mathrm{SE})$ as shown in the annual hydrograph record. In a normal monsoon year, the minimum water discharge $\left(0.8-1.4 \mathrm{~m}^{3} \mathrm{~s}^{-1}\right)$ by watershed is observed in the summer months followed by a sudden peak $\left(12-18 \mathrm{~m}^{3} \mathrm{~s}^{-1}\right)$ in the monsoon month. In winters, the mean discharge varies between 1.5 and $2.5 \mathrm{~m}^{3} \mathrm{~s}^{-1}$ (tables 2 and 3 ). Thus, the watershed has the capacity to generate maximum flood during monsoon (68\% of the total volume) as compared to winter (20\%) and summer $(12 \%)$ seasons.

The response of the watershed in terms of discharge to the extreme rainfall regimes was quite different. In a normal rainfall year (2008-2009), the mean discharge was $5.12 \pm 1.75 \mathrm{~m}^{3} \mathrm{~s}^{-1}$ (CV: $120 \%$ ), whereas in a drought year (2009-2010; $1265 \mathrm{~mm})$, it reduced to $3.6 \pm 0.9 \mathrm{~m}^{3} \mathrm{~s}^{-1}$ (CV: $85 \%$ ). Thus, with the reduction in $\sim 23 \%$ rainfall, discharge from watershed declined by $\sim 30 \%$. In an excessive rainfall year (2010-2011; $3041 \mathrm{~mm})$, the mean discharge from the watershed peaked up to $8.45 \pm 3.9$ $\mathrm{m}^{3} \mathrm{~s}^{-1}$ (CV: 159\%) (figure 3). The rainfall event in 2010 was a once-in-a-century event, during which the discharge was $\sim 200 \%$ higher relative to regional average. Rainfall alone explained more than $85 \%$ of the discharge variations in this typical Lesser Himalayan watershed with $\sim 45 \%$ vegetation cover. Probably because of significant vegetation cover in the watershed (Chauhan et al. 2016) the correlation coefficient $(r)$ between discharge and rainfall was found highest in the drought year (figure 3a).

\subsection{Suspended and dissolved load transport behaviour}

Temporal variations in total suspended solid (TSS) and dissolved solid (TDS) had a significant effect on annual sediment transport behaviour in the watershed systems. Based on the values of TSS and TDS at the sampling station, the annual sediment transport behaviour is presented in figure 4. Interannual mean TSS and TDS was $4027 \pm 1566$ and $2134 \pm 762$ metric tons, respectively. Monsoon months accounted for $97 \%$ and $93 \%$ of the annual load transport, respectively. More than 200\% upsurge in total solid load was observed in the excessive rainfall year (2010) (figure 4c). It is interesting to note similar behaviour of TDS in normal and drought years, whereas suspended solid (TSS) varied significantly $(30 \%)$ in both the years. Consistently, dissolved load was found higher than suspended load in the drier months (winter, summer). The annual sum and monthly suspended and dissolved sediment transport are shown in tables 2 and 3 . In winter

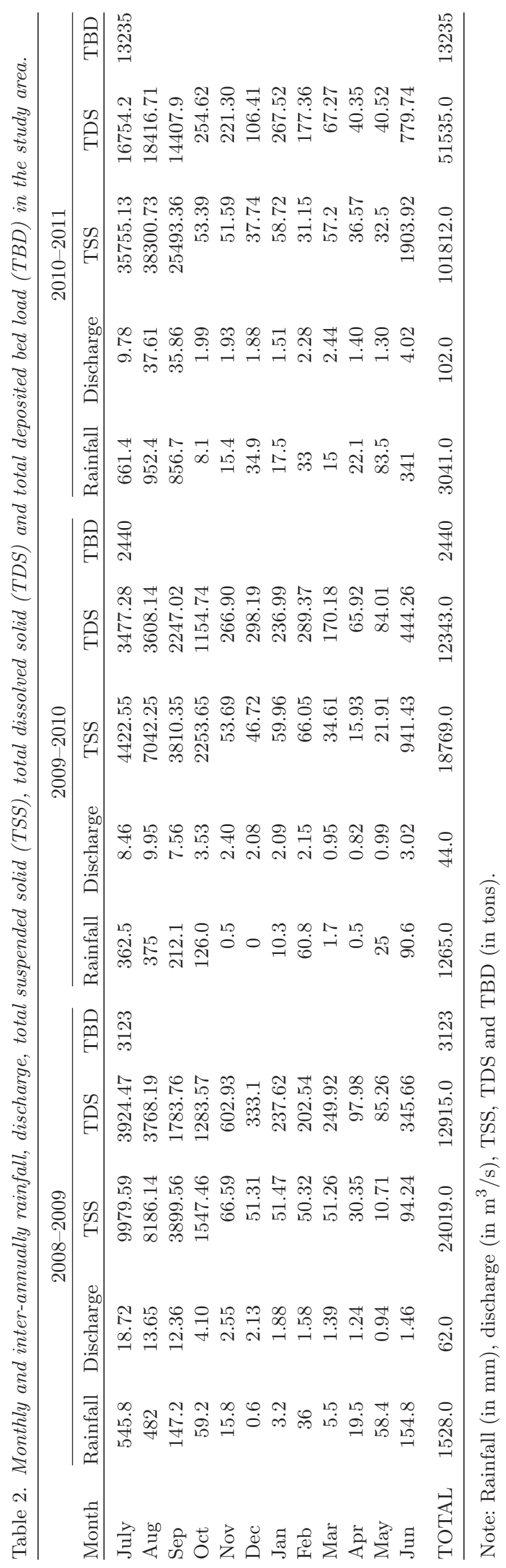


Table 3. Year-wise precipitation, discharge, total suspended solid (TSS), total dissolved solid (TDS), total deposited bed load (TBD), chemical erosion, mechanical erosion and total erosion rates in the study sub-watershed.

\begin{tabular}{lcccccccc}
\hline Years & Rainfall & Discharge & TSS & TDS & TBD & $\begin{array}{c}\text { Chemical } \\
\text { erosion }\end{array}$ & $\begin{array}{c}\text { Mechnical } \\
\text { erosion }\end{array}$ & $\begin{array}{c}\text { Total } \\
\text { erosion }\end{array}$ \\
\hline $2008-2009$ & 1528 & 62 & 24019 & 12915 & 3123 & 0.12 & 0.24 & 0.36 \\
$2009-2010$ & 1265 & 44 & 18769 & 12343 & 2440 & 0.11 & 0.19 & 0.30 \\
$2010-2011$ & 3041 & 102 & 101812 & 51534 & 13235 & 0.46 & 1.03 & 1.50 \\
\hline
\end{tabular}

Note: Rainfall in $\mathrm{mm}$, discharge in $\mathrm{m}^{3} \mathrm{~s}^{-1}$, TSS, TDS, TBD in tons and chemical, mechanical and total

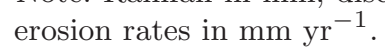

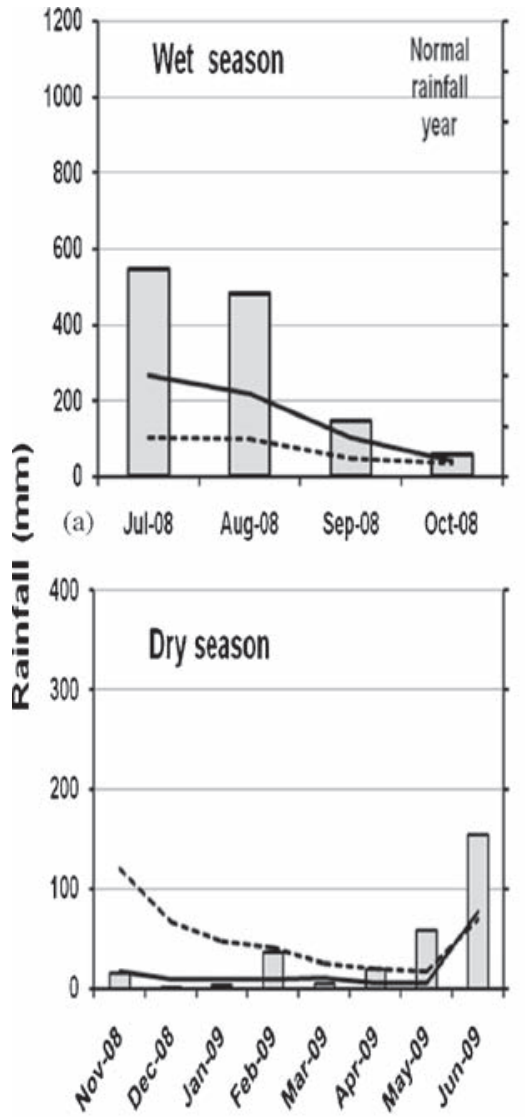

(d)
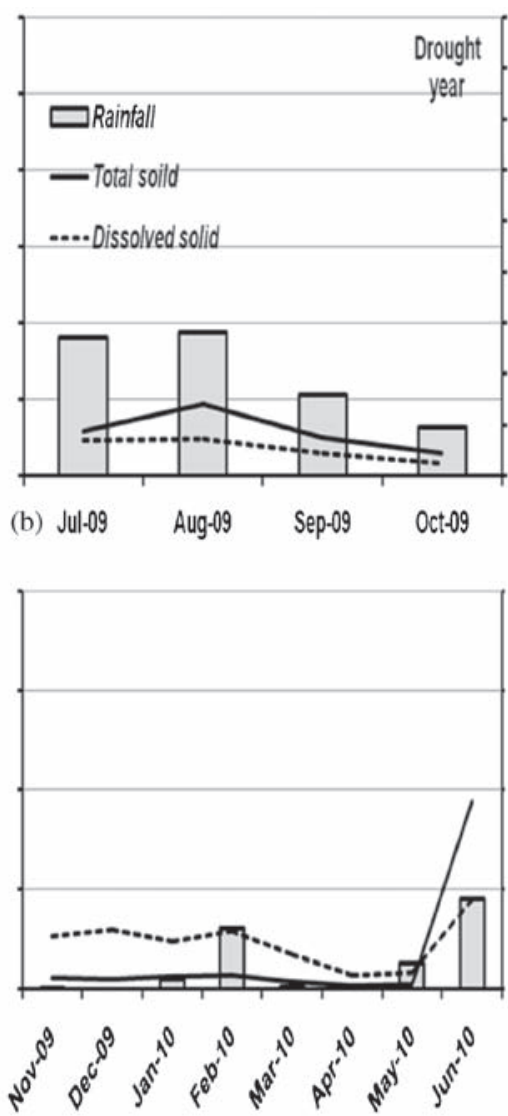

(e)
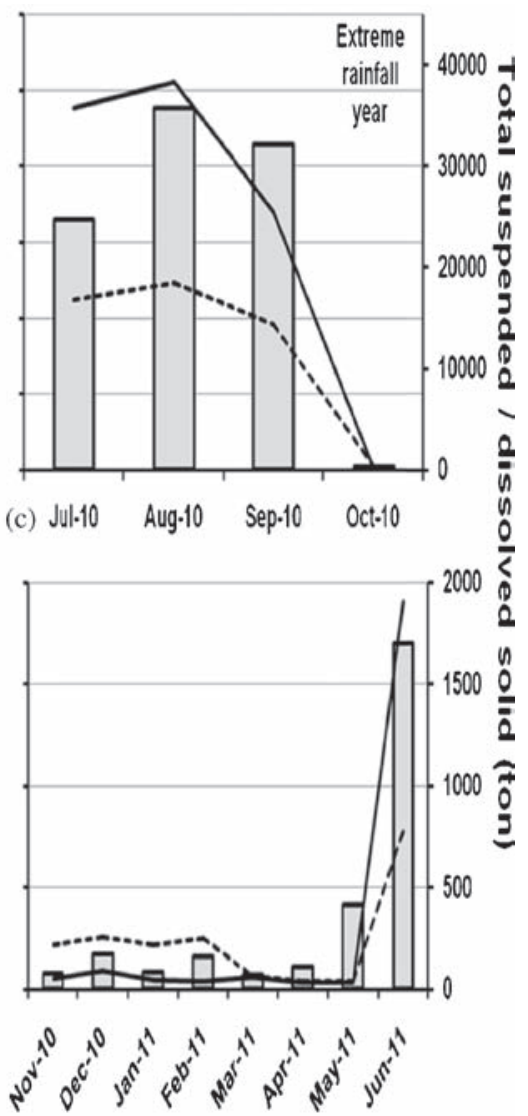

(f)

Figure 4. (a-f) Temporal relation between rainfall and load (total suspended and dissolved) transport behaviour in different precipitation regimes and in dry season.

and summer seasons, average suspended sediment was noted at $5 \%$ and $8 \%$, respectively.

\subsection{Physical and chemical erosion in the watershed}

The TDS/TSS ratio (C/P: chemical and physical weathering) for the sampling site was observed to be $<1$ for the wet season (figure 5), indicating the overall dominance of TSS over the TDS. However, higher $\mathrm{C} / \mathrm{P}$ ratio (1-7) at the mainstream and substreams suggested that they are chemically more active in dry season. Interestingly, the differences in $\mathrm{C} / \mathrm{P}$ ratio during different hydrological years were not found statistically significant. Generally, the $\mathrm{C} / \mathrm{P}$ ratio decreases with the increase of watershed area (Singh et al. 2008). However, the $\mathrm{C} / \mathrm{P}$ ratio in the present study does reflect a constant interannual trend reflecting minor changes in human activity and vegetation cover. $\mathrm{C} / \mathrm{P}$ ratio was inversely $\left(R^{2}=0.49\right)$, but significantly $(P<0.001)$ related to the rainfall. This shows that erosion rate is closely linked to rainfall and runoff and its relation with the tectonics remains invariant in the region.

It has also been observed that the $\mathrm{pH}$ value of the Tons River basin is slightly higher, which shows alkaline nature. The comparison of the alkalinity 


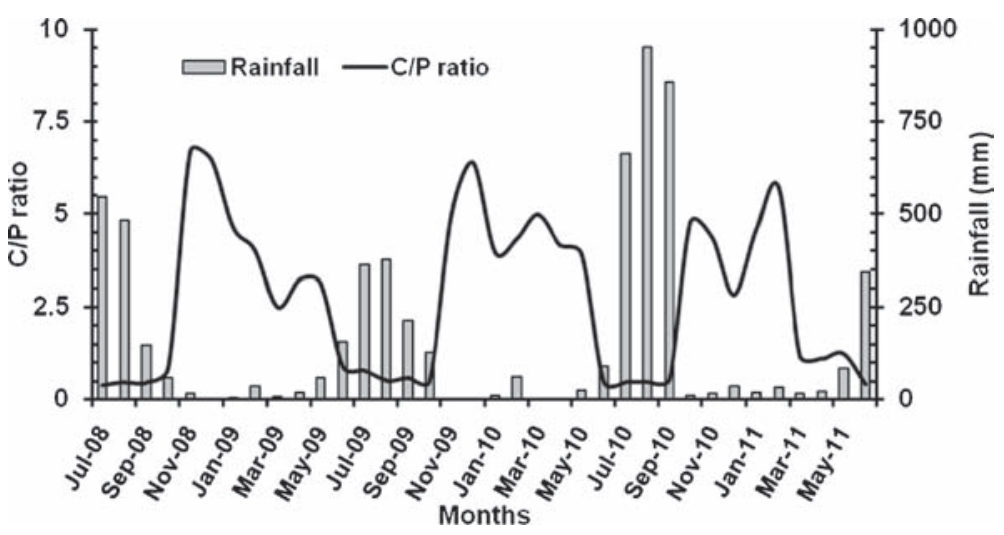

Figure 5. The relationship between chemical (C) and physical (P) erosion rate in relation to dry and wet seasons.

Table 4. Comparison of the alkalinity levels in the Himalayan and Indian rivers with river of study watershed. (Subramanian 1979; Kumar 1987; Singh et al. 2008).

\begin{tabular}{lc}
\hline Rivers & $\mathrm{pH}$ value \\
\hline Major Indian rivers & \\
Cauvery & 7.8 \\
Gandak & 7.3 \\
Godavari & 7.1 \\
Krishna & 7.5 \\
Mahanadi & 8.0 \\
Narmada & 7.2 \\
Tungabadra & 7.5 \\
Himalayan rivers & \\
Brahmaputra & 7.1 \\
Chenab & 7.7 \\
Dhauli Ganga & 8.0 \\
Ganga & 7.6 \\
Jhelum & 7.5 \\
Sainj & 8.2 \\
Tirthan & 7.6 \\
Tons River basin (present study) & 8.1 \\
\hline
\end{tabular}

levels of the Tons River basin and some other Indian rivers are presented in table 4 . The study reveals higher alkalinity level in the Tons River compared to other Indian rivers, due to the rock types and soil, such as presence of limestone, can neutralize acid more effectively than other types of rock and soil.

\subsection{Deposited bed load}

As the sub-watershed forms a fan-shaped feature, only coarse material settle down there, allowing fine sand and clay to wash-out under fast-flowing runoff on the hilly landform. The efforts have been made to measure year-wise deposited bed load as given in tables 2 and 3 . It reveals that in the first normal monsoon year (2008-2009), 3123 ton $\mathrm{yr}^{-1}$ bed load was deposited by the river, 2440 ton $\mathrm{yr}^{-1}$ in the second drought year (2009-2010) which was the minimum load observed. Exceptionally high bed load (13235 ton $\mathrm{yr}^{-1}$ ) was deposited during 2010-2011 in the extreme rainfall year.

\subsection{Watershed denudation rate}

Denudation rates have been estimated based on the total sediment and total dissolved load discharged by the watershed at the sampling station. The chemical, mechanical and gross denudation rates have been obtained by using the total sediment budget (Gregory 1979; Rawat et al. 2012a). In the present case, three years data have been analyzed for denudation rates as shown in table 5 , which shows that the gross rate of erosion for the first year (2008-2009) was $0.36 \mathrm{mmyr}^{-1}$. The chemical and mechanical erosion rates for the same year were 0.12 and $0.24 \mathrm{mmyr}^{-1}$, respectively. In the second year (2009-2010), the gross, chemical and mechanical rates were estimated at $0.3,0.11$ and $0.19 \mathrm{mmyr}^{-1}$, respectively. The gross erosion rate for the third year (2010-2011) (extreme rainfall year) was about five times higher $\left(1.5 \mathrm{mmyr}^{-1}\right)$. The chemical and mechanical rates were 0.46 and $1.03 \mathrm{mmyr}^{-1}$, respectively. Thus, the average denudation rate of the Tons sub-watershed has been estimated at $0.33 \mathrm{mmyr}^{-1}$ (excluding extreme rainfall year: $1.5 \mathrm{mmyr}^{-1}$ ). Thus, it can be concluded that Tons River basin is lowering in the range between 0.3 and $0.36 \mathrm{mmyr}^{-1}$, excluding once-in-a-century rainfall event (2010).

\section{Discussion}

In this study, the response of a sub-tropical western Lesser Himalayan watershed to different rainfall regimes has been elucidated. We tried to understand the impacts on discharge, erosion, sediment flux and denudation rates in three entirely different hydrological years: a normal monsoon year 
Table 5. Selected denudation rates for the Himalayan Region from different sources (after Ramasay 1986).

\begin{tabular}{|c|c|c|c|}
\hline Location & $\begin{array}{l}\text { Denudation rate } \\
\qquad\left(\mathrm{mm} \mathrm{yr}^{-1}\right)\end{array}$ & Comments & Author \\
\hline $\begin{array}{l}\text { Tons River basin, Mussoorie } \\
\text { Garhwal Lesser Himalaya }\end{array}$ & 0.33 & From sediment yield & Present study \\
\hline Punatsanchhu, River Bhutan & 0.28 & From sediment yield & Sonam Choden (2009) \\
\hline R. Arun watershed & 0.51 & From sediment yield & $\begin{array}{l}\text { Williams and Berndt (1977), } \\
\text { after Das (1968) }\end{array}$ \\
\hline $\begin{array}{l}\text { Kosi Basin, Dabka watershed, } \\
\text { Kumaun Lesser Himalaya }\end{array}$ & 0.68 & From sediment yield & Rawat et al. (2012b) \\
\hline Himalaya & 1.00 & Regional & Menard (1961) \\
\hline Ganges/Brahmaputra watershed & 0.70 & $\begin{array}{l}\text { From present rate of influx } \\
\text { to Bay of Bengal Fan }\end{array}$ & Curray and Moore (1971) \\
\hline R. Hunza watershed & 1.80 & From sediment yield & Fergusson (1984) \\
\hline R. Tamur watershed & 5.14 & From sediment yield & Seshadri (1960) \\
\hline $\begin{array}{l}\text { Kosi River, Khulgad watershed } \\
\text { Kumaun Lesser Haimalaya }\end{array}$ & 1.11 & From sediment yield & Rawat (2010) \\
\hline $\begin{array}{l}\text { Gaula river basin, Kumaun } \\
\text { Lesser Himalaya }\end{array}$ & 1.70 & From sediment yield & Valdiya and Bartarya (1989) \\
\hline
\end{tabular}

(2008-2009), a drought year (2009-2010) and extreme precipitation event (2010-2011). In recent times, the hydrology of the geologically precarious Himalayan terrain has received considerable attention among researchers and planners as government's push for the sustainable multipurpose small hydropower plants (SHPPs) for augmenting rural Himalayan economy. However, due to uncertain minimum base flow rate/discharge and suspected higher rate of reservoir sedimentation, the sustainability of many of these projects is debatable.

Geologically, the study area comes under tectonically weak formations and is also affected by the limestone quarrying in the past (Prasad and Dave 2012). Unstable and hilly terrain, prone to landslides and erosion has caused accelerated attrition during the rainy season. Mean interannual water discharge $\left(5.74 \pm 1.44 \mathrm{~m}^{3} \mathrm{~s}^{-1}\right)$ was found to be variable $\left(0.8-38 \mathrm{~m}^{3} \mathrm{~s}^{-1}\right)$ (CV: $\left.151 \%\right)$. During the rainfall event in 2010, discharge was $\sim 200 \%$ higher compared to the long-term regional average. In the eastern and western Lesser Himalayan watersheds, estimated runoff range similar to our results has been reported (Bajracharya et al. 2004; Rawat et al. 2011, 2012b; Bisht et al. 2016). The discharge flow from the watershed even during the driest period was found to be sufficiently high to run turbines for power production (Hosseinia et al. 2005; Sharma and Ripendra 2013). Sediment budget and rate of denudation for this middle order stream and 4th order stream of the Tons watershed in the Lesser Himalaya shows that range of erosion is between 0.3 and $0.36 \mathrm{mmyr}^{-1}$. An extreme rainfall year could increase the erosion rate maximum up to five times, defining upper threshold limit for the reservoir sedimentation.
Several environmental variables, i.e., topography, hydroclimatology, land use and soil erodibility, affect the sediment yield and erosion rate (Ali and De Boer 2007). The pronounced effect of the seasonality on sediment transport is evident in this sub-tropical Lesser Himalayan watershed. The majority of the sediment load was in the form of TSS and was mostly transported during the monsoon months. The amount of TDS increased downstream, due to joining of various small streams in the main channel. The observed high TDS in dry season relative to wet season (figure $4 \mathrm{~d}-\mathrm{f}$ ) was due to the minimal rainfall in this period. The TDS content was highest during monsoon, which could be attributed to high seasonal flows. It appears that the dry season could be important for chemical processes and the wet season may be critical for sediment mass transfer due to the high intensity of rainfall and mass wasting phenomenon in the watersheds. The TDS/TSS ratio $(\mathrm{C} / \mathrm{P}$ : chemical and physical weathering) was observed to be less than one for the wet season (figure 5), indicating overall dominance of TSS over the TDS. However, higher $\mathrm{C} / \mathrm{P}$ ratio $(1-7)$ at the mainstream and sub-streams suggested that they are chemically more active in the dry season. Interestingly, the differences in $\mathrm{C} / \mathrm{P}$ ratio during different hydrological years were not found statistically significant. Irrespective of the rainfall behaviour in the three years, TDS/TSS $(\mathrm{C} / \mathrm{P})$ ratio was consistently low $(<1)$ during monsoon months and higher (1-7) during rest of the dry period. $\mathrm{C} / \mathrm{P}$ ratio was inversely $\left(R^{2}=0.49\right)$, but significantly $(P<0.001)$ related to the rainfall.

The maximum (4.75 times) bed load in the third year (2010-2011) may be because of heavy rainfall and landslides, where loose materials directly 
reached the main river by rainwater contributing to a heavy bed load. The amounts of bed load depend on the intensity and duration of rainfall, peak runoff and anthropogenic activities like mining, tourism, road and dam constructions. Based on the dataset of this study, it is observed that human impact is more dangerous than natural processes of land degradation. Table 5 shows the comparative denudation rates from different regions in the Himalaya. In the present study, the rate is lower than the average rate of the Himalaya (1.0 $\mathrm{mmyr}^{-1}$ ), Ganga-Brahmaputra basin: (0.70 mmyr $\left.{ }^{-1}\right)$, Dabka watershed: $\left(0.68 \mathrm{mmyr}^{-1}\right)$. However, the denudation rates estimated by several researchers in the regional watershed (Hunza watershed: $1.80 \mathrm{mmyr}^{-1}$, Khulgad watershed: 1.11 mmyr ${ }^{-1}$, Gaula watershed: $1.70 \mathrm{mmyr}^{-1}$ ), were comparatively higher than the present study denudation rate $\left(0.33 \mathrm{mmyr}^{-1}\right)$ in the Tons River basin. Few studies even reported lower rate, e.g., Punatsanchhu River in Bhutan (0.28 $\left.\mathrm{mmyr}^{-1}\right)$, and Arun watershed $\left(0.51 \mathrm{mmyr}^{-1}\right)$. It may be due to the vegetation cover and new plantations in the catchment for eco-restoring the degraded ecosystems (Prasad and Dave 2012). Many factors influence the rates of erosion, i.e., specific area of the watershed, specific gravity of the rock, slope, rainfall, land use pattern, landslides, and developmental work which contribute to the world wide variations (Gregory and Walling 1973). Local and regional denudation rates always vary. Locally determined rates could be strongly influenced by the focussed action of a geomorphic agent and such rates are likely to vary in time and space compared to larger area (Burbank and Beck 1991). Fluvial erosion rates generally decrease with larger catchments size (Milliman and Meade 1983; Milliman and Syvitski 1992).

Thus, subsequently analyzing the water discharge, runoff, sediment rate and other topographical parameters, enhanced with the ground verifications, a suitable site could be proposed for the installation of a SHPP. The Tons River basin has adequate mean interannual average discharge $\left(5.74 \mathrm{~m}^{3} \mathrm{~s}^{-1}\right)$ and suitable relative relief $(1430 \mathrm{~m})$, relief ratio (0.11) and basin slope $\left(6.6^{\circ}\right)$ (Chauhan et al. 2016). This demonstrates a better capacity to produce sufficient runoff. In the study area itself (figure 1), India's second oldest Glaogi Hydroelectric Power Station built in $1907\left(30^{\circ} 25^{\prime} 36^{\prime \prime} \mathrm{N}\right.$; $78^{\circ} 4^{\prime} 11^{\prime \prime} \mathrm{E}$ ), on Kiarkuli river (a tributary of Tons) is working sustainably. The Uttarakhand Jal Vidyut Nigam Ltd. has estimated discharge at $1.32 \mathrm{~m}^{3} \mathrm{~s}^{-1}$ and it is generating $3.0 \mathrm{MW}$ power. In the present study, the annual hydrograph record shows discharge at an average rate of $5.74 \mathrm{~m}^{3} \mathrm{~s}^{-1}$, which is sufficient amount of flow to run the turbines and another SHPP can be proposed on Bhitarli River (another tributary of Tons) (Chauhan et al. 2016). With an average flow of $1.78 \mathrm{~m}^{3} \mathrm{~s}^{-1}$, the estimated hydropower potential may be about 1.30 MW in mountainous terrain (Fagbohun 2016).

Although, 3 years of denudation and sedimentation results are presented here, this short period of study is not sufficient to arrive at significant conclusion. The study area is very sensitive, since it is mountainous and landslide-affected region. Therefore, necessary efforts should be made to communicate an eco-friendly strategy for integrated sustainable development of the Lesser Himalayan watersheds. Modern techniques and long-term automated measurements of the hydro-metrological parameters are required to estimate the accurate denudation rate in the mountainous watersheds.

\section{Conclusions}

The understanding of the hydrological processes such as discharge and sediment flux of a watershed is crucial for its management and sustainable exploitation of the water resource. In this study, the response of a Lesser western Himalayan watershed in terms of discharge, sediment flux and denudation has been estimated in three entirely different hydrological years. The study site is a representative of the region in the Lesser western Himalaya, where several SHPPs are being planned for augmenting the rural economy. In this view, our results on discharge, sediment budget and the rates of denudation for a middle order stream and 4th order stream of the Tons watershed suggest that range of erosion is between 0.3 and $0.36 \mathrm{mmyr}^{-1}$. An extreme rainfall year could increase the erosion rate up to five times, defining upper threshold limit for reservoir sedimentation, whereas discharge could be as high as $\sim 200 \%$. The watershed has the capacity to generate maximum flood during monsoon ( $68 \%$ of the total volume) as compared to winter $(20 \%)$ and summer $(12 \%)$ seasons. $23 \%$ reduction in rainfall could decline the discharge by $\sim 30 \%$. Rainfall explained $\sim 85 \%$ of the discharge variation in this typical Lesser Himalayan watershed with $\sim 45 \%$ vegetation cover. Mean interannual water discharge $\left(5.74 \pm 1.44 \mathrm{~m}^{3} \mathrm{~s}^{-1}\right)$ is highly variable $\left(0.8-38 \mathrm{~m}^{3} \mathrm{~s}^{-1}\right)$, but sufficient to run turbines for SHPPs even during dry seasons.

Locating a sustainable site for installation of a new plant is one of the main difficulties for small-scale hydroelectric power generation. Thus, subsequently analyzing the water discharge, runoff, sediment rate and other topographical parameters, enhanced with the ground verification, a suitable location at the study site could be proposed 
for the installation of a small hydro-power plant (1-5 MW). The Tons River basin has adequate mean interannual average discharge, suitable relative relief, relief ratio and favourable slope for setting up the proposed SHPP.

Our results will be worthwhile in planning to reduce the inflow of silt into the reservoir, conserve soil and minimize run-off in the extreme rainfall years. Results will cater to planners and engineers for formulating strategies to control erosion and landslides for watershed management on precursory basis. The outcomes of this study will also be useful in understanding the geographic conditions and hydrological behaviour (discharge and sediment flux) of the basin in the context of setting up small hydropower plants in the region. The study will also act as a valuable reference for hydropower station management and governmental oversight.

\section{Acknowledgements}

Authors are grateful to the support and necessary facilities extended by the Director, Wadia Institute of Himalayan Geology, Dehradun to carry out this study. The authors also thank the editor and anonymous reviewers for their insightful and constructive comments that helped to improve this manuscript.

\section{References}

Ali K F and De Boer D H 2007 Factors controlling specific sediment yield in the upper Indus River basin, northern Pakistan; Hydrol. Process. 22(16) 3102-3114.

Bajracharya R M, Sharma S and Clemente R 2004 Discharge and sediment loads of two streams in the mid-hills of central Nepal; Himalayan J. Sci. 2(3) 51-54.

Barnard P L, Owen L A, Sharma M C and Finkel R C 2001 Natural and human induced landsliding in the Garhwal Himalaya of northern India; Geomorphology 40 21-35.

Bartarya S K 1988 Geohydrological and geomorphological studies of the Gaula river basin (district Naini Tal) with special reference to the problem of erosion; Unpublished Ph.D thesis; Kumaun University, Nainital.

Bisht S, Sharma S and Chaudhry S 2016 Flash flood risk susceptibility in Gagas River Watershed-Kumaun Lesser Himalaya; Int. J. Adv. Remote Sens. GIS 5(5) 1709-1725.

Buchanan T J and Somers W P 1969 Discharge measurements at gaging stations: U.S Geological Survey Techniques of Water-Resources Investigations; book $\mathbf{3}$, chapter A8, 65p.

Bhutiyani M R 2000 Sediment load characteristics of a proglacial stream of Siachen Glacier and the erosion rate in Nubra valley in the Karakoram Himalayas, India; $J$. Hydrol. 227(1) 84-92.

Burbank D W and Beck R A 1991 Rapid long term rates of denudation; Geology 19 1169-1172.

Caine N and Swanson F J 1989 Geomorphic coupling of hillslope and channel systems in small mountain basins; Zeitschrift für Geomorphologie 33(2) 189-203.

Chauhan P, Chauniyal D D, Singh N and Tiwari R K 2016 Quantitative geo-morphometric and land cover based micro-watershed prioritization in the Tons River basin of the Lesser Himalaya; J. Environ. Earth Sci. 75 498, doi: $10.1007 / \mathrm{s} 12665-016-5342-\mathrm{x}$.

Chaudhary R S and Sharma P D 1999 Runoff and sediment yield from Giri river catchment in Himachal Pradesh; Indian J. Soil Conserv. 27(1) 1-9.

Choden S Lund 2009 Sediment transport studies in Punatsangchu River, Bhutan; Master Project TVVR 09/5005, ISRN LUTVDG/TVVR-09/5005 ISSN-11019824 .

Curray J R and Moore D G 1971 Growth of the Bengal deepsea fan and denudation in the Himalayas; Geol. Soc. Am. Bull. 82(3) 563-572.

Das K N 1968 Soil erosion and the problem of silting in the Kosi catchment; J. Soil Water Conserv. India 16(3-4) 60-67.

Dimri A P, Thayyen R J, Kibler K, Stanton A, Jain S K, Tullos D and Singh V P 2016 A review of atmospheric and land surface processes with emphasis on flood generation in the southern Himalayan rivers; Sci. Total Environ. 556 98-115.

Fagbohun O O 2016 Studies on small hydro-power potentials of Itapaji Dam in Ekiti State, Nigeria; Int. J. Eng. Sci. Inven. 2319-6734, ISSN (Print) 2319-6726.

Fergusson R I 1984 Sediment load of Hunza river; In: International Karakoram Project 2 (ed.) Miller K J, Cambridge University Press, Cambridge, pp. 581-597.

Good S P, Noone D and Bowen G 2015 Hydrologic connectivity constrains partitioning of global terrestrial water fluxes; Science 349(6244) 175-177.

Gregory J K and Walling D E 1973 Drainage Basin Form and Process: A Geomorphological Approach; Edward Arnold, London, 456p.

Gregory K J 1979 Drainage network power; Water Resour. Res. 15(4) 775-777.

Grinsted A, Moore J C and Jevrejeva S 2004 Application of the cross wavelet transform and wavelet coherence to geophysical time series; Nonlin. Process. Geophys. 11 561-566.

Hosseinia S M H, Forouzbakhshb F and Rahimpoora M 2005 Determination of the optimal installation capacity of small hydro-power plants through the use of technical, economic and reliability indices; J. Energy Policy 33 1948-1956.

Jha P K, Subramanian V and Sitasawad R 1988 Chemical and sediment mass transfer in the Yamuna River a tributary of the Ganges system; J. Hydrol. 104(1) $237-246$.

Kesharwani M K 2006 Overview of small hydro power development in the Himalayan region; Himalayan Small Hydropower Summit (October 12-13 2006); Dehradun, India.

Kumar P 1987 Geomorphological evaluation of environmental degradation and management in Dhauliganga Basin (Central Himalayas); Ph.D. thesis, Jawaharlal Nehru University, New Delhi, India.

Lehmann J, Coumou D and Frieler K 2015 Increased recordbreaking precipitation events under global warming; Climatic Change 132(4) 501-515.

Lupker M, Blard P H, Lave J, France-Lanord C, Leanni L, Puchol N, Charreau J and Bourles D $2012{ }^{10}$ Be-derived Himalayan denudation rates and sediment budgets in the Ganga basin; Earth Planet. Sci. Lett. 333-334 $146-156$.

Menard H W 1961 Some rates of regional erosion; J. Geol. 69(2) 154-161.

Milliman J D and Meade R H 1983 World-wide delivery of river sediment to the oceans; J. Geol. 91 1-21.

Milliman J D and Syvitski J P M 1992 Geomorphic/ tectonic control of sediment discharge to the ocean: The 
importance of small mountainous rivers; J. Geol. 100 $525-544$.

Nagle G N, Fahey T J and Lassoie J P 1999 Management of sedimentation in tropical watersheds; Environ. Manag. 23(4) 441-452.

Pradhan P M S 2004 Improving Sediment Handling in the Himalayas; Hydro Lab Pvt. Ltd. GPO Box 21093; Kathmandu, Nepal.

Prasad B and Dave A 2012 Geology of Lesser Himalaya sequences in Mussoorie Syncline around DehradunMussoorie area (field excursion by Society for Petroleum Geophysicists (SPG)).

Rao S V N, Rao M V and Ramasasitri K S 1997 A study of sedimentation in Chenab Basin in western Himalayas; Nord. Hydrol. 28 201-216.

Rawat J S 2010 Database management system for Khulgad watershed, Kumaun Lesser Himalaya, Uttarakhand, India; Curr. Sci. 98(10) 1340-1348.

Rawat P K, Tiwari P C, Pant C C, Sharma A K and Pant P D 2011 Modelling of stream run-off and sediment output for erosion hazard assessment in the Lesser Himalaya: Need for sustainable land use plan using remote sensing and GIS: A case study; Nat. Hazards 59 1277-1297.

Rawat P K, Tiwari P C, Pant C C, Sharma A K and Pant P D 2012a Geo-hydrological database modeling for integrated multiple hazards and risk assessment in Lesser Himalaya: A GIS-based case study; Nat. Hazards 62 1233-1260.

Rawat P K, Tiwari P C, Pant C C, Sharma A K and Pant P D 2012b Spatial variability assessment of river-line floods and flash floods in Himalaya: A case study using GIS; Disaster Prev. Manag. 21(2) 135-159.

Rawat J S and Rai S P 1997 Pattern and intensity of erosion in the environmentally stressed Khulgad watershed, Kumaun Himalaya; J. Geol. Soc. India 50(3) 331-338.

Rawat J S and Rawat M S 1994 Accelerated erosion and denudation in the Nana Kosi watershed, central Himalaya, India; Part I: Sediment Load; Mt. Res. Dev. 14(1) 25-38.

Seshadri T N 1960 Report on Kosi River and its behaviour. Investigation and research, Dn Khosi project, Birpur, Cited in: Brunsden et al. 1981 (q.v.).

Sharma P P, Gupta S C and Rawls W J 1991 Soil detachment by single raindrops of varying knit energy; Soil Sci. Soc. Am. J. 46 117-121.
Sharma R H and Ripendra A 2013 Hydropower development in Nepal; Renew Sust. Energ. Rev. 21 684-693.

Singh S K, Rai S K and Krishnaswami S 2008 Sr and Nd isotopes in river sediments from the Ganga Basin: Sediment provenance and spatial variability in physical erosion; J. Geophys. Res. 113 F03006, doi: 10.1029/2007 JF000909.

Singh O, Sharma M C, Sarangi A and Singh P 2008 Spatial and temporal variability of sediment and dissolved loads from two alpine watersheds of the Lesser Himalayas; Catena 76 27-35.

Sitaula B P, Garde M, Burbank D W, Oskin M, Heimsath A and Gabet E 2007 Bed load to suspended load ratio and rapid bedrock incision from Himalayan landslide-dam lake record; Qua. Res. 68 111-120.

Srivastava M 2005 Biodiversity study in natural forests abandoned mine and ecorestored mine habitats of Mussoorie Hills; Bull. Nat. Inst. Ecol. 16 59-68.

Subramanian V 1979 Chemical and suspended sediment transport characteristics of rivers of India; J. Hydrol. 44 $37-55$.

Thomas F S and Christoph C R 2005 Water cycle shifts gear; Nature 434 830-833.

Torrence C and Compo G P 1998 A practical guide to wavelet analysis; Bull. Am. Meteor. Soc. 79 61-78.

Valdiya K S and Bartarya S K 1989 Mass-movements in a part of Kumaun Himalaya; Curr. Sci. 58(9) 486-491.

Weerakoon S B and Rathnayake U S 2007 Effect of the entrance zone on the trapping efficiency of desilting tanks in run-of-river hydropower plants; International Conference on Small Hydropower - Hydro Sri Lanka, 22-24 October.

Williams J R and Berndt H D 1977 Sediment yield prediction based on watershed hydrology; Trans. Amer. Sot. Agr. Eng. 20 1100-1104.

Wolman M G 1954 A method of sampling coarse river-bed material; EOS Trans. AGU 35(6) 951-956.

Xiaoping Y 2003 Manual of sediment management and measurement. World Meteorological Organization Operational Hydrology Report No. 47 Secretariat of World Meteorological Organization; Geneva, Switzerland.

Yadav R and Sri Ram 2014 Landslides and its remedial measures in Mussoorie hilly sections; Int. J. Sci. Res. Dev. 2(10) $842-851$. 